\title{
肌の白さの嗜好に関する比較文化的研究 日本とインドネシアの比較
}

\section{早稲田大学 齋藤美穂}

A cross-cultural study on preference for lightness of complexions: Comparison between Japan and Indonesia Miho Saito (School of Human Sciences, Waseda University, Mikajima, Tokorozawa 359)

Using 176 Japanese and 132 Indonesian university students as subjects, the author investigated the preference for light complexions and the cultural influence on it from the viewpoint of the psychological structure of the aesthetic preference for white. In the first survey, the subjects were asked to choose their preferred colors from a color chart in order to know their general preference for white. In the second survey, the subjects were asked to answer a questionnaire designed to discriminate personal images for the four stimuli of different complexion. The results showed that positive images were associated with a fair complexion in Japan. In Indonesia, on the other hand, the images associated with a fair complexion were rather negative although white itself was highly accepted. Association with images of rareness and scarcity for a fair complexion was, however, common to both countries. This may suggest that the preference for white and whiteness derives from images of something unique and special.

Key words: colors, preferences, preferences for complexions, cross-culture, personal images.

白に対する嗜好順位が，我が国における色見本を使 用した選択法による色彩嗜好調査結果の中で比較的上 位に出現し始めるのは Tsukada，Funatsu，\& Sato (1964）の研究以降であり，その後の日本色彩研究所 (1992) による嗜好調査結果の継年変化および齋藤・ 冨田・向後 (1991)，また齋藤・冨田・山下 (1991) による東京・大阪・福岡・富山の 4 都市で実施した調 查結果からも日本での白嗜好は高く安定していること が確認されている。また齋藤（1981）は日本人の色彩 嗜好傾向を欧米など九つの文化的グループの間で比較 し，日本での白墸好の高さは他の文化的グループには 観察されない傾向であることを報告した。更にこの研 究に抢ける分析の中で得られたD-score の值を各地域 で検討してみると，日系アメリカ人は日本人よりもア メリカ人に近い色彩嗜好傾向をもつことがわかり，色 彩嗜好に対して居住地域の文化的環境要因の影響性を 示唆する結果となった。文化的環境要因が色彩嘹好に 影響を与えると思われる結果は既存の研究でも報告さ れている.よってこのような文化的・環境的側面が仮 に色彩嗜好の影響要因として重要なものであるなら ば，日本で観察された白嗜好が地理的・文化的に近い と考えられる周辺のアジアの地域でも観察される可能

1 本研究は財団法人コスメトロジー研究振興財団からの 1992 年度助成研究である。
性があると考え，まずソウルと東京との色彩嗜好傾向 の比較（齋藤，1992）を行い，続いて天津，台北，東 京での比較研究を実施した (Saito, 1994)。その結果, 白㖦好は他の周辺アジア地域でも観察され，むしろそ の傾向は日本を上回っていることがわかった。

白に対する嗜好理由を調査の自由回答から探ると， 東京やソウルでは “清潔感”や “純粋”が主な理由と なっているが，天津や台北では“純潔”が最も多く, 時には白に対する “神聖視”も見られた。日本文化の 中でも白に対する神聖視は, 神道における天照大御神 のような太陽信仰とのかかわりで説明されている。こ こでの白は太陽の光の色という意味をもつ。神道の素 木造りの神殿や御幣などに見られる白の使用も，生な りの無垢なものや清らかなものとしての白と考えられ ている。このように白が好ましいとされた背景には 光，すなわち明るさとのかかわりが多分に見られる.

ところで肌の色に扔いても，見た目の肌の白さは主 にその明るさと関連する。 また肌の色に対して日本で は古くから白さを好ましいとするような表現がある。 そこで本研究ではこのような白嗜好が関連していると 思われる具体的事象として，肌の白さに対する嗜好を 研究し白嗜好とのかかわりを検討することとした，肌 の白さのように具体的事象になった場合，これまでの 色紙の白への嗜好とは異なり生活文化といった面での 影響を一層強く受けるものと考えられる。特に肌の色 
Table 1

日本とインドネシアにおける嗜好色と嫌悪色の順位一覧表

\begin{tabular}{|c|c|c|c|c|c|c|c|c|}
\hline & \multicolumn{4}{|c|}{ 嗜好色 } & \multicolumn{4}{|c|}{ 嫌悪色 } \\
\hline & \multicolumn{2}{|c|}{ 日本 } & \multicolumn{2}{|c|}{ インドネシア } & \multicolumn{2}{|l|}{ 日本 } & \multicolumn{2}{|c|}{ インドネシア } \\
\hline 1st & vivid-blue & $\begin{array}{l}32.0 \% \\
* * *\end{array}$ & white & $\begin{array}{l}24.2 \% \\
* * *\end{array}$ & olive & $\begin{array}{l}23.4 \% \\
* * *\end{array}$ & gold & $\begin{array}{l}29.9 \% \\
* * *\end{array}$ \\
\hline 2nd & white & $\begin{array}{l}16.0 \% \\
* * *\end{array}$ & $\begin{array}{l}\text { vivid-blue/ } \\
\text { black }\end{array}$ & $\begin{array}{l}19.1 \% \\
19.1 \% \\
* * *\end{array}$ & gold & $\begin{array}{l}16.0 \% \\
* * *\end{array}$ & dark-blue & $\begin{array}{l}15.3 \% \\
* * *\end{array}$ \\
\hline $3 \mathrm{rd}$ & vivid-red & $\begin{array}{l}12.0 \% \\
* * *\end{array}$ & & & grayish-pink & $\begin{array}{l}12.0 \% \\
* * *\end{array}$ & $\begin{array}{l}\text { vivid-red/ } \\
\text { vivid-yellow/ } \\
\text { silver }\end{array}$ & $\begin{array}{c}14.6 \% \\
14.6 \% \\
14.6 \% \\
* * *\end{array}$ \\
\hline 4 th & $\begin{array}{c}\text { vivid-green/ } \\
\text { pale-sky }\end{array}$ & $\begin{array}{l}9.7 \% \\
9.7 \% \\
* * *\end{array}$ & light-blue & $\begin{array}{l}16.6 \% \\
* * *\end{array}$ & dark-red & $\begin{array}{l}10.3 \% \\
* * *\end{array}$ & & \\
\hline 5 th & & & light-green & $\begin{array}{l}12.1 \% \\
* * *\end{array}$ & $\begin{array}{c}\text { dark-yellowish- } \\
\text { brown/ } \\
\text { dark-gray }\end{array}$ & $\begin{array}{l}9.7 \% \\
9.7 \% \\
* * *\end{array}$ & & \\
\hline 6 th & $\begin{array}{l}\text { pale-greenish- } \\
\text { sky }\end{array}$ & $\begin{array}{l}9.1 \% \\
* * *\end{array}$ & pale-sky & $\begin{array}{l}10.8 \% \\
* * *\end{array}$ & & & $\begin{array}{c}\text { dark-red-purple/ } \\
\text { black }\end{array}$ & $\begin{array}{l}13.4 \% \\
13.4 \% \\
* * *\end{array}$ \\
\hline 7 th & $\begin{array}{l}\text { pale-green/ } \\
\text { light-green/ } \\
\text { deep-blue }\end{array}$ & $\begin{array}{l}8.6 \% \\
8.6 \% \\
8.6 \% \\
* * *\end{array}$ & $\begin{array}{l}\text { pale-greenish- } \\
\text { sky/ } \\
\text { vivid-red }\end{array}$ & $\begin{array}{l}10.2 \% \\
10.2 \% \\
* * *\end{array}$ & $\begin{array}{l}\text { grayish-yellow- } \\
\text { green }\end{array}$ & $\begin{array}{l}8.6 \% \\
* * *\end{array}$ & & \\
\hline 8 th & & & & & $\begin{array}{l}\text { vivid-purple/ } \\
\text { medium-gray }\end{array}$ & $\begin{array}{l}8.0 \% \\
8.0 \% \\
* *\end{array}$ & olive-yellow & $\begin{array}{l}10.8 \% \\
* * *\end{array}$ \\
\hline 9 th & & & light-violet & $\begin{array}{l}8.9 \% \\
* * *\end{array}$ & & & dark-red & $\begin{array}{l}9.6 \% \\
* * *\end{array}$ \\
\hline 10th & vivid-yellow & $\begin{array}{l}8.0 \% \\
* *\end{array}$ & pink & $\begin{array}{l}8.3 \% \\
* *\end{array}$ & $\begin{array}{c}\text { beige/ } \\
\text { dark-red-purple }\end{array}$ & $\begin{array}{l}7.4 \% \\
7.4 \% \\
*\end{array}$ & vivid-purple & $\begin{array}{l}8.9 \% \\
* * *\end{array}$ \\
\hline
\end{tabular}

${ }^{* * *} p<.001,{ }^{* *} p<.01,{ }^{*} p<.05$ (by binominal test)

への嗜好は文化的環境要因の影響がより多く考えられ る具体的事象と思われる。よってこの肌の白さに対す る咾好が地理的・文化的に異なる環境においてどのよ うな傾向を示すかを検討する。

色彩への嗜好は形態や材質という他の属性の影響を 受けることは従来の研究からも明らかであるが，ここ で肌の色を取り上げ，地理的文化的に異なる地域で比 較することの意義は，もし肌の色への嗜好がその地域 での文化や一般的な肌の色への考え方などの上に成り 立っているのだとしたならば，仮に色紙における白嗜 好が観察されたとしても, 明るい肌の色は必ずしも好
まれないのではないかと仮定するからである。またも しそうであるのなら肌の色の好ましさの基準は文化に よって異なると仮定できる可能性もあるからである。

本研究の調査対象地域は日本とインドネシアとし た. 研究は調査 1 と調査 2 により構成されているが, 調查 1 では選択法により得た両地域の一般的嗜好色に おける白に対する嗜好とその選択理由を確認し, 続く 調査 2 では主として明るさ（白さ）の異なる 4 種類の 肌色刺激に対する評価語との関連を検討した。 


\section{調 査 1}

\section{目 的}

両地域の一般的嗜好色における白への嗜好傾向を探 ると共にその選択理由を得ることを目的とした。

\section{方 法}

被験者 東京の日本人大学生 176 名（男性 90 名, 女性 86 名), 平均年歯 21.3 歳, およびジャカルタの インドネシア人大学生 132 名（男性 68 名, 女性 64 名), 平均年齢 24.8 歳. 被験者総数 308 名（男性 158 名, 女性 150 名).

刺激 ニュートラルグレーの A3 判台紙に貼付され た 77 色のカラーチップ（各 $2.0 \mathrm{~cm} \times 3.5 \mathrm{~cm}$ ) で構成 されたカラーチャートを使用. 有彩色 70 色（10 色 相×7トーン)，無彩色 5 色および金色と銀色.

手続き 被験者にはカラーチャートを見ながら嗜好 色と嫌悪色を 3 色ずつ 1 位から 3 位まで選択すると同 時に選択理由も答えてもらい，この結果をもとに一般 的咾好順位を得た。使用照明は蛍光灯で 1 人一 3 人を 同時に面接した。実施期間は1992 年 4 月から 1994 年 1 月である。

\section{結 果}

Table 1 は両地域の選択色の順位を嗜好色と嫌悪色 のそれぞれについて上位 10 位まで一覽表にしたもの である。この中で白の嗜好のみに着目するならば，白 は両地域に扔いて非常に好まれる色であることがわか る.またその傾向は日本よりむしろインドネシアで上 回っていることも明らかとなった。

この白に対する選択理由を調べてみると日本では “清潔”が最も多く，その次に“純粋”“きれい”“何 とでも調和する”“明るくはっきりしている”“太陽の 光に近い”“すっきりしている”“さっぱりしている” “さわやか”“飾られていない”“安心する”“目をひ く”“やさしい”などが続く、インドネシアでもやは り “清潔”が第 1 の選択理由であるが “純潔（純潔の 象徴も含む)”“明るい”“中立”という理由も多く見 られる。その他 “何色とでも調和する” “上品”“涼し い”“自然”“落ち着いた”“権威のある”などが多い 理由であった。また両地域とも“けがれのない清潔さ と明るさ”が共通した嗜好理由であることがわかっ た。

嫌悪色として白が選択されることは日本では全くな かったが，インドネシアでは $3.2 \%$ (5人) あり，そ の理由としては“明るすぎる”“污れやすい”“単純” という理由が主なものであった。

\section{目 的}

調査 1 では, 白への嗜好が両地域とも高く, また白 のもつ“けがれのない清挲さと明るさ”が両地域に共 通した嗜好理由であることが明らかとなった。

調査 2 では，この白の嗜好が肌の白さというものに 対してどのように関連してくるか検討することを目的 とする.このために主として明るさの異なる 4 種類の 肌色刺激に対して 52 項目からなる評価語との関連を 検討することにより白への嗜好性を肌の白さ（明る さ）に対する心理的側面から探ってみることとした。

\section{方 法}

\section{被験者 調査 1 と同様.}

刺激 多数の日本人の肌色の測定から日本人の代表 的な肌色を分類した肌色調查結果（小林，1967）に基 づき，ナチュラル肌の肌色色票から代表的な以下の 4 種を刺激とした. 括弧内はJIS 記号.これらの肌色色 票を B5 判の大きさで作成し, その上に女性の顔の輪 郭 (Figure 1) が描かれた OHP シートを重ね, これ をもって 4 枚 1 組の刺激とした。

刺激 1：色白肌（5.0YR 7.5/4.0）

刺激 2 : 普通肌の色白寄り (5.0YR 7.0/5.0)

刺激 3 : 普通肌の色黒寄り $(5.0 \mathrm{YR} 6.5 / 5.0)$

刺激 4 : 色黒肌 (5.0YR 6.0/5.0)

手続き 白さ（明るさ）は多分に相対的な関係も考 えられるので, 1 組中の 4 刺激を 1 より順に左から同 時提示し，被験者にはそれらを見ながら，Table 2 の ような 52 項目よりなる評価語（容貌を手がかりとし たパーソナリティーイメージの因子分析結果（岩下, 1983）を参考にして選出）に対して最も適切だと思う 順番に刺激の順位付けをしてもらった.この手続きに より得られた結果に対し，各評価語に対して順位づけ

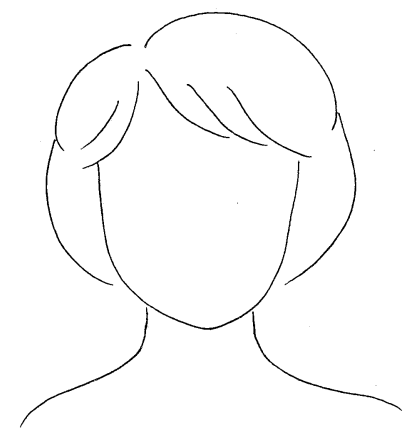

Figure 1. OHP シートに描かれた女性の顔の輪郭図 (実物の刺激は B5 判大) 
Table 2

日本語とインドネシア語による評価語一覧

\begin{tabular}{|c|c|c|c|}
\hline \multicolumn{4}{|c|}{ 評価語 } \\
\hline & 日本語 & & インドネシア語 \\
\hline 01) & 美しい & 01) & cantik \\
\hline 02) & 明るい感じ & 02) & cerah \\
\hline 03) & 女性的な感じ & 03) & feminim \\
\hline 04) & りこうそうな感じ & 04) & cerdas \\
\hline 05) & 親しみやすい感じ & 05) & ramah tamah \\
\hline 06) & ふけた感じ & 06) & kelihatan tua \\
\hline 07) & のんびりした感じ & 07) & santai \\
\hline 08) & 貧相な感じ & 08) & miskin \\
\hline 09) & 派手な感じ & 09) & nyolok \\
\hline 10) & 柔らかい感じ & 10) & lembut \\
\hline 11) & はきはきとした感じ & 11) & tegas \\
\hline 12) & 近づきやすい感じ & 12) & mudah bergaul \\
\hline 13) & 古くさい感じ & 13) & kuno \\
\hline 14) & いやらしい感じ & 14) & rasa jijik \\
\hline 15) & 陽気な感じ & 15) & riang \\
\hline 16) & 丸みのある感じ & 16) & kelihatan bulat \\
\hline 17) & きりっとした感じ & 17) & kelitatan rapi \\
\hline 18) & 好き & 18) & senang \\
\hline 19) & 落ち着いた感じ & 19) & rasa tenang \\
\hline 20) & 弱々しい感じ & 20) & kelihatan lemah \\
\hline 21) & 知性的な感じ & 21) & intelek \\
\hline 22) & モダンな感じ & 22) & modern \\
\hline 23) & 育ちがよい感じ & 23) & rasa terpelihara \\
\hline 24) & うわべだけの感じ & 24) & rasa tidak tulus \\
\hline 25) & 可愛らしい感じ & 25) & lucu \\
\hline 26) & 静かな感じ & 26) & rasa sepi \\
\hline
\end{tabular}

られた刺激の第 1 選択に着目して数量化 III 類による い”，“可愛らしい”というイメージがインドネシアよ 分析を行った。使用照明・聴取法・実施期間は調査 1 と同様.

\section{結 果}

刺激 1 (色白肌) に関する分析結果 Table 3 は, 刺激 1 を第 1 選択とした評価語を, 選択率順に上位 15 位まで示した一覧表である. 刺激 1 が第 1 選択に なった評価語として総合的に最も多かったものは “弱々しい”の 275 反応であった. Table 3 から両地 域とも色白肌は“弱々しい”イメージと最も結びつい ている点は共通しており, そのほかに共通してもたれ ているイメージの上位には，“貴族的な”，“デリケー 卜な”，“静かな”，“育ちがよい”，“保守的な”，“清潔 な”が見られる。

しかし日本では, “抒とない”, “上品”, “消極 的”, “女性的”, “ていねいな”, “柔らかい”, “美し

\section{評価語}

$$
\text { 日本語 }
$$

インドネシア語

27）軽い感じ

28）意志が強そうな感じ

29）貴族的な感じ

30）保守的な感じ

31）善人のような感じ

32）デリケートな感じ

33）特色のある感じ

34）清潔な感じ

35）ていねいな感じ

36）うちとけた感じ

37）幼い感じ

38）上品な感じ

39）愉快な感じ

40）ねちねちした感じ

41）消極的な感じ

42) やさしい感じ

43）おとなしい感じ

44) 甘い感じ

45）うすっぺらな感じ

46）あたたかい感じ

47）あじわいがある感じ

48）しゃれた感じ

49）女らしくない感じ

50）おだやかな感じ

51）いばった感じ

52）魅力的

27) rasa ringan

28) semangatnya besar

29) bangsawan

30) tertutup

31) baik hati

32) mudah tersinggung

33) rasa bersifat istimewa

34) rasa bersih

35) sopan

36) terbuka

37) belum dewasa

38) anggun

39) gembira

40) murung

41) perasaan negatif

42) lemah-lembut

43) patuh

44) lalai

45) pemikirannya dangkal

46) perrasaan hangkat

47) menawan hati

48) pesolek

49) tidak feminim

50) rasa damai

51) sombong

52) menarik

りも多く選択され, インドネシアでは, むしろ“いば つた”，“派手な”イメージや“特色のある”, “しゃれ た”イメージ，また“幼い”，“軽い”，“明るい”，“き りっとした”というイメージが日本より多く選択され ているのがわかる。

また Table 4 の 1\%水準で有意に多く選択された評 価語を眺めてみると, このほかに日本では“知性的 な”, “おだやかな”, “古くさい”, “のんびりした”, “落ち着いた”等，むしろ静的なイメージがもたれて いるのに対して，インドネシアでは“愉快な”, “陽気 な”等, 動的なイメージを色白肌に抱いていることが わかった。

Table 5 は両地域の性別における比較であるが, 日 本の男性に特に多く見られる評価語は，“ていねいな” と“知性的な”であり，女性では，“可愛らしい”と “甘い”であることがわかる。“おとなしい”と“柔ら 
Table 3

刺激 1 (色白肌)に対する評価語の上位一覧表

\begin{tabular}{|c|c|c|c|c|}
\hline & \multicolumn{2}{|c|}{ 日本 } & \multicolumn{2}{|c|}{ インドネシア } \\
\hline & 評価語 & $\begin{array}{c}\text { 選択率 } \\
(\%)\end{array}$ & 評価語 & $\begin{array}{c}\text { 選択率 } \\
(\%)\end{array}$ \\
\hline 1 位 & 弱々しい & 92.0 & 弱々しい & 85.6 \\
\hline 2 位 & 貴族的な & 86.4 & 清潔な & 85.6 \\
\hline 3 位 & デリケートな & 85.8 & いばった & 78.0 \\
\hline 4 位 & 静かな & 83.5 & 貴族的な & 71.2 \\
\hline 5 位 & おとなしい & 83.0 & 幼い & 70.5 \\
\hline 6 位 & 上品な & 81.3 & しゃれた & 70.5 \\
\hline 7 位 & 育ちがよい & 79.5 & 明るい & 65.2 \\
\hline 8 位 & 消極的な & 77.3 & 派手な & 59.8 \\
\hline 9 位 & 女性的な & 75.8 & きりっとした & 59.1 \\
\hline 10 位 & 保守的な & 71.0 & 特色のある & 59.1 \\
\hline 11 位 & 清潔な & 69.9 & 保守的な & 56.8 \\
\hline 12 位 & ていねいな & 68.2 & デリケートな & 56.8 \\
\hline 13 位 & 柔らかい & 64.8 & 静かな & 55.3 \\
\hline 14 位 & 美しい & 60.8 & 育ちがよい & 54.5 \\
\hline 15 位 & 可愛らしい & 55.1 & 軽い & 53.0 \\
\hline
\end{tabular}

かい”というイメージも女性の方がより多く選んだ評 価語と考えられる，インドネシアの男性の方に多く見 られる評価語としては, “きりっとした”と“やさし い”であり，女性では，“うわべだけの”と“保守的 な”が多く選ばれたが，“しゃれた”というイメージ も女性の方に多く選択されていた。

上述のことからも両地域における色白肌への評価が 異なっているようであることがわかるが, 更に数量化 III 類により結果を分析してみた. Figure 2 は数量化 III 類による分析でのカテゴリースコアを 1 軸と 2 軸 によりプロットしたものである.1軸は, 陰気で消極 的な感じか, 陽気で活発な感じかを分ける軸であり, 積極性・消極性の軸と言えよう。それに対し 2 軸はう わべだけの表層的な感じか, あたたかい善人そうな感 じかを分けている軸のようである.

Figure 3 の日本とインドネシアの性別および国別の プロットを含めて考え合わせると，インドネシアでは 日本に比べ色白肌に対して“特色のある”イメージ (I；59.1\%++，J；10.2\%--) 2や“しゃれた”（I； $70.5 \%++, \mathrm{J} ; 37.5 \%--)$ “明るい”イメージ（I；

2 括弧内のI, I-m, I-f, J, J-m, J-f はそれぞれインドネシア，イ ンドネシア男性, インドネシア女性, 日本, 日本男性, 日本女 性を示す.
Table 4

$1 \%$ 水準で有意差のあった評価語

\begin{tabular}{|c|c|c|}
\hline 地 域 & 評価語 & $\begin{array}{c}\text { 選択率 } \\
(\%)\end{array}$ \\
\hline \multirow[t]{22}{*}{ 本 } & 貴族的な & 86.4 \\
\hline & デリケートな & 85.8 \\
\hline & 静かな & 83.5 \\
\hline & おとなしい & 83.0 \\
\hline & 上品な & 81.3 \\
\hline & 育ちがよい & 79.5 \\
\hline & 消極的な & 77.3 \\
\hline & 女性的な & 75.6 \\
\hline & 保守的な & 71.0 \\
\hline & ていねいな & 68.2 \\
\hline & 柔らかい & 64.8 \\
\hline & 美しい & 60.8 \\
\hline & 可愛らしい & 55.1 \\
\hline & 知性的な & 50.0 \\
\hline & おだやかな & 50.0 \\
\hline & のんびりした & 49.4 \\
\hline & 古くさい & 48.3 \\
\hline & 落ち着いた & 42.6 \\
\hline & りこうそうな & 37.5 \\
\hline & 善人のような & 36.9 \\
\hline & 貧相な & 32.4 \\
\hline & ふけた & 30.7 \\
\hline \multirow[t]{13}{*}{ インドネシア } & 清潔な & 85.6 \\
\hline & いばった & 78.0 \\
\hline & 幼い & 70.5 \\
\hline & しゃれた & 70.5 \\
\hline & 明るい & 65.2 \\
\hline & 派手な & 59.8 \\
\hline & きりっとした & 59.1 \\
\hline & 特色のある & 59.1 \\
\hline & 軽い & 53.0 \\
\hline & うわべだけの & 43.2 \\
\hline & あじわいがある & 34.8 \\
\hline & 陽気な & 28.0 \\
\hline & 愉快な & 27.3 \\
\hline
\end{tabular}

65.2\%++，J； 36.4\%--) はもっているようであ るが，同時に“いばった” (I；78.0\%++，J；26.1

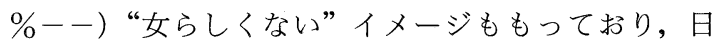
本人がもっているような “女性的” (J; 75.6\%++, I；25.8\%-ー) で“おだやかな” (J；50.0\%++, I ; 29.5\%-ー) “のんびりした” (J；49.4\%++，I； 20.5\%-ー）イメージはあまりもたれていないことが わかる。特に“うわべだけ”の表層的なイメージの方 
Table 5

刺激 1 (色白肌)に対する評価語の上位一覧表——性別による比較—

\begin{tabular}{|c|c|c|c|c|c|c|c|c|}
\hline \multirow{2}{*}{ 順位 } & \multicolumn{2}{|c|}{ 日本男性 } & \multicolumn{2}{|c|}{ 日本女性 } & \multicolumn{2}{|c|}{ インドネシア男性 } & \multicolumn{2}{|c|}{ インドネシア女性 } \\
\hline & 評価語 & $\begin{array}{c}\text { 選択率 } \\
(\%)\end{array}$ & 評価語 & $\begin{array}{c}\text { 選択率 } \\
(\%)\end{array}$ & 評価語 & $\begin{array}{c}\text { 選択率 } \\
(\%)\end{array}$ & 評価語 & $\begin{array}{c}\text { 選択率 } \\
(\%)\end{array}$ \\
\hline 1 位 & 弱々しい & 92.2 & 弱々しい & 91.9 & 清潔な＋ & 86.8 & 弱々しい & 85.9 \\
\hline 2 位 & 貴族的な + & 88.9 & おとなしい++ & 90.7 & 弱々しい & 85.3 & 清潔な & 84.4 \\
\hline 3 位 & デリケートな+十 & 84.4 & デリケートな++ & 87.2 & いばった++ & 77.9 & しゃれた +十 & 81.3 \\
\hline 4 位 & 静かな＋ & 81.1 & 静かな ++ & 86.0 & 貴族的な & 73.5 & いばった++ & 78.1 \\
\hline 5 位 & 上品な＋＋ & 81.1 & 貴族的な & 83.7 & 幼い+ & 72.1 & 保守的な & 71.9 \\
\hline 6 位 & 育ちがよい十 & 77.8 & 上品な＋＋ & 81.4 & 明るい++ & 67.6 & 貴族的な一 & 68.8 \\
\hline 7 位 & 消極的な ++ & 76.7 & 育ちがよい+＋ & 81.4 & きりっとした++ & 66.2 & - & 68.8 \\
\hline 8 位 & おとなしい+ & 75.6 & 消極的な ++ & 77.9 & 派毛な＋＋ & 66.2 & 特色のある十+ & 67.2 \\
\hline 9 位 & 清潔な & 74.4 & 女性的な+＋ & 77.9 & しゃれた & 60.3 & デリケートな & 64.1 \\
\hline 10 位 & 女性的な+十 & 73.3 & 柔らかい＋＋ & 72.1 & 育ちがよいーー & 52.9 & 明るい十 & 62.5 \\
\hline 11 位 & 保守的な & 71.1 & 可愛らしい++ & 72.1 & 静かなーー & 51.5 & 静かなー & 59.4 \\
\hline 12 位 & $\begin{array}{l}\text { ていねいな+ } \\
\text { 知性的な+ }\end{array}$ & 66.7 & 保守的な & 70.9 & $\begin{array}{l}\text { 軽い+ } \\
\text { 特色のる }++\end{array}$ & $\begin{array}{l}51.5 \\
51.5\end{array}$ & 育ちがよいー & 56.3 \\
\hline 13 位 & & & 清潔なーー & 65.1 & & & 軽い++ & 54.7 \\
\hline 14 位 & 美しい & 60.0 & 甘い++ & 62.8 & デリケートなーー & 50.0 & うわべだけの＋＋ & 54.7 \\
\hline 15 位 & 柔らかい & 57.8 & 美しい+ & 61.6 & やさしい & 48.5 & 派手な＋+ & 53.1 \\
\hline
\end{tabular}

注）表中に十+および-ーとあるのはパーセントにおける有意差検定において $1 \%$ 水準で有意差の見られたものであ り,十およびーとあるのは，5\%水準で有意差のある場合を示す.いずれの場合もその評価語に対する総合的な選択率に対し て，各カテゴリーの選択率が相対的に有意に高いか低いかを示すものである.

向にベクトルが向いているのは，インドネシア人女性 の方であることがこの図からもわかる（J-m；21.1 \%-—, J-f ; $37.2 \%$, I-m ; $32.4 \%$ I - f ; 54.7 $\%++)$. インドネシア人男性の方は, 女性に比べる と“きりっとした”，“陽気な”（J-m； 7.8\%-，J-f； $4.7 \%--$ I-m；32.4\%，I-f；23.4\%）イメージの方 向にベクトルが向いている.

日本人男性は，“善人のような”（J-m； 44.4\%++， J-f ; 29.1\%, I-m;22.1\%, I-f；14.1\%--), “りこう そうな” (J-m；45.6\%++, J-f；29.1\%, I-m ; 27.9 $\%$, I-f；14.1\%--), “好き” (J-m;44.4\%++, J$\mathrm{f} ; 31.4 \%$, I-m;29.4\%, I-f；25.0\%), “意志の強そ うな” (J-m;22.2\%++, J-f； $4.7 \%--$, I-m ; 14.7 \%, I-f；7.8\%）等の方向にべクトルが向いているが, 日本女性の特徴は, “貧相な”の方向にべクトルが向 いていることである. 刺激 1 に対して日本人全体とし てはポジティブなイメージを抱いているものの，日本 女性の中では“貧相な”というイメージをもっている 被験者が男性より若干多かったことに起因する（J$\mathrm{m} ; 30.0 \%+$, J-f ; 34.9\%++, I-m ; 5.9\%--, If $; 4.7 \%--)$.
刺激 2 (普通肌の色白寄り) に関する分析結果 刺 激 2 を第 1 選択とした評価語として総合的に最も多か ったものは“近づきやすい”の149 反応であった．両 地域に共通して多く選ばれた評価語は“好き”, “おだ やかな”, “魅力的”, “知性的な”, “りこうそうな”, “モダンな”，“美しい”，“善人のような”であった。 日本の上位評価語の中でインドネシアの上位評価語に 挙がらなかったものは, “うすっぺらな”, “近づきや すい”, “親しみやすい”，“あたたかい”，“うちとけ た”, “明るい”，“可愛らしい”であり，逆にインドネ シアの上位評価語の中で日本の上位評価語に登場しな かったものは，“女性的な”，“柔らかい”, “あじわい がある”, “陽気な”，“上品な”，“ていねいな”等，日 本が主に刺激 1 (色白肌) に対して選択していた評価 語が多く含まれていたことが興味深い.

その他の評価語でインドネシアに $1 \%$ 水準で有意に 多く観察された評価語は, “のんびりした”, “愉快 な”，“きりっとした”，“育ちがよい”，“特色のある”, “軽い”, “抢となしい”, “貴族的な”であり, 日本で は, “清潔な”, “甘い”, “保守的な”, “いやらしい”, “ふけた”が挙がっていた。 


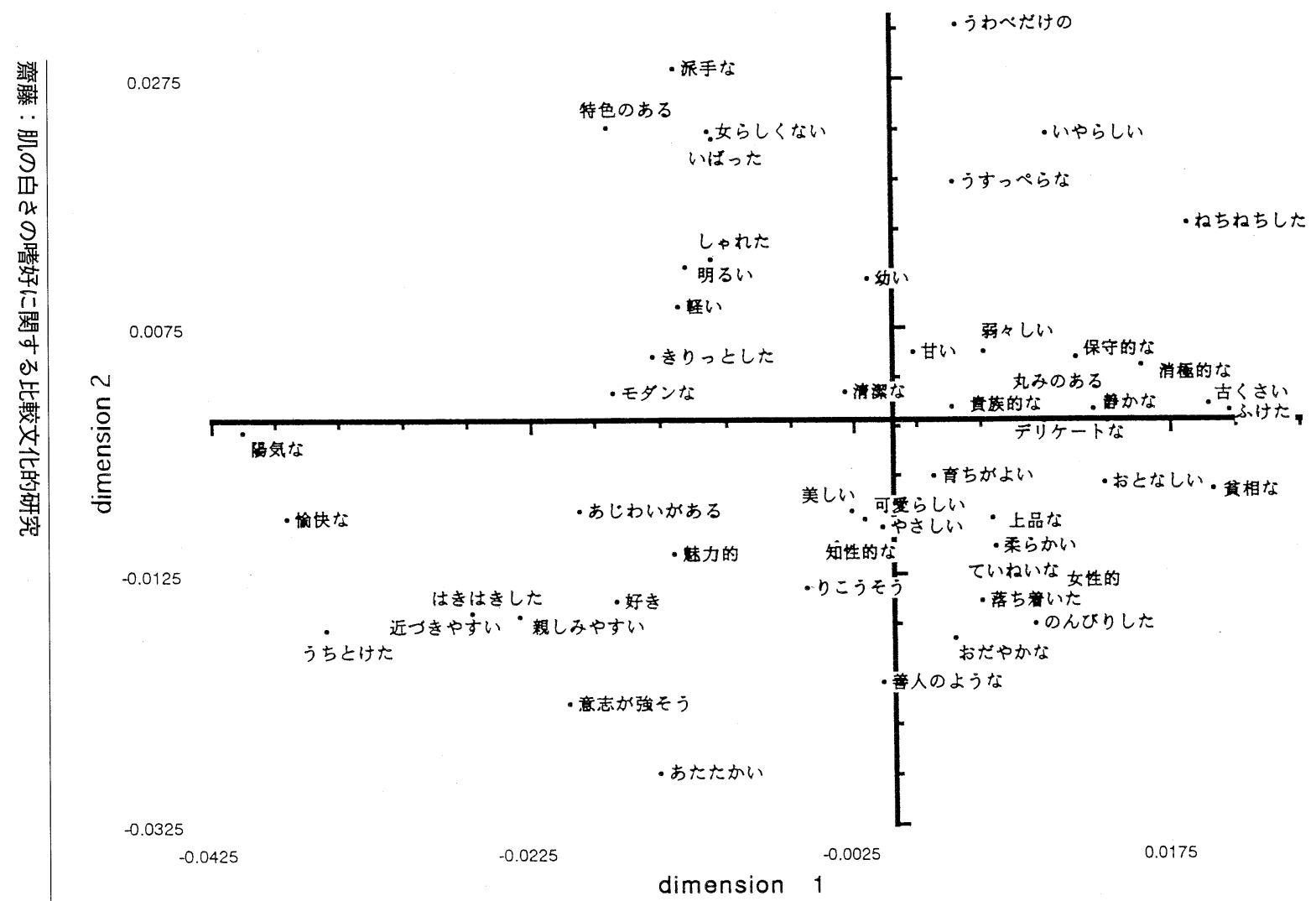

Figure 2. 刺激 1 (色白肌) を第 1 選択にした場合の 数量化 III 類による分析結果 (1 軸 $\times 2$ 軸).

0.006

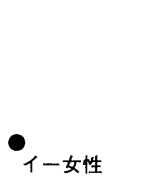

0.004

インドネシア人

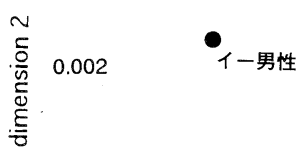

$0 \longdiv { \text { 男性 } }$

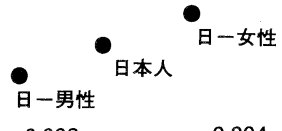

$-0.004$

$-0.002$

0.002

dimension 1

Figure 3. 地域別・性別に関する数量化 III 類による 分析 (1 軸 $\times 2$ 軸). 
日本の男性が特に多く選択していた評価語は, “可 愛らしい”であり, “やさしい”, “美しい”, “柔らか い”という評価語も女性より多く選択された。 日本女 性の場合は“明るい”, “落ち着いた”, “知性的な”, “あじわいがある”，“モダンな”が男性の上位評価語 には見られない特徴的なものであった.インドネシア の男性の場合は，“モダンな”，“うちとけた”，“愉快 な”，“あたたかい”が多く，またインドネシアの女性 の場合は，“美しい”，“善人のような”，“知性的な”, “親しみやすい”，“のんびりした”が特徵的なもので あった.インドネシアの場合, “女性的な”イメージ を普通肌の色白寄り（刺激 2) に抱いているが（I； $56.8 \%, \mathrm{~J} ; 17.6 \%)$ ，その傾向は特にインドネシア人 女性の方に多く見られた（男性； $44.1 \%$ ，女性； 70.3 $\%$ ).

数量化 III 類による 1 軸と 2 軸のプロットから刺激 2 に対する両地域の特徴を探ると, インドネシアでは この刺激に対して “女性的”（I；56.8\%++, J ; 17.6 $\%--)$ で“上品” (I； 45.5\%++, J ; 14.8\%--) で “貴族的” (I $; 21.2 \%++, \mathrm{J} ; 7.4 \%--)$ なイメ ージを抱いているのに対し，日本では“うすっぺら” $(\mathrm{J} ; 55.7 \%++$, I ; 8.3\%--), “消極的” ( $\mathrm{J} ; 10.2$ $\%++$, I ; 5.3\%--), “保守的” ( $\mathrm{J} ; 18.2 \%++$, I；5.3\%-—）なイメージをもつているのがわかっ た。またインドネシアの男性の場合，“特色のある” (J-m;6.7\%--, J-f ; 17.4\%, I-m ; 35.3\%++, I$\mathrm{f} ; 21.9 \%)$, “抢となしい” (J-m; $12.2 \%$, J-f ; 3.5 $\%-ー, \mathrm{I}-\mathrm{m} ; 29.4 \%++$, I-f；23.4\%）イメージとの 関連が見られるのに対し，インドネシアの女性の場合 は“きりっとした”（J-m；18.9\%-，J-f；20.9\%，I$\mathrm{m} ; 30.9 \%$, I-f； 42.2\%++）イメージとの関連もあ るようだ。いずれにしてもポジティブな傾向をもつ評 価語はインドネシアの方向に，ネガティブな傾向をも つ評価語は日本の方向に二分されており, 両地域のこ の刺激に対する評価の違いが明らかとなった。

刺激 3 (普通肌の色黒寄り) に関する分析結果 刺 激 3 を第 1 選択とした評価語として総合的に最も多か ったものは“親しみやすい”の 81 反応であり，この 反応数を他の刺激に対する反応数と比較すると 4 刺激 中で最も第 1 選択になりにくかった刺激であったこと がわかる。

両地域に共通して多く選ばれた評価語としては, “親しみやすい”, “意志が強そうな”, “うちとけた”, “愉快な”，“近づきやすい”，“あたたかい”，“落ち着 いた”，“陽気な”，“はきはきとした”であるが，この うち，“はきはきとした”という評価語はインドネシ アでは第 1 位となっているのに対し，日本では 15 位 である。また日本で多く選ばれた評価語はインドネシ アで上位に選ばれた評価語と異なっていた。すなわち 日本の上位評価語は, “ふけた”, “あじわいがある”,
“貧相な”，“ねちねちした”，“モダンな”，“古くさい” のようにネガティブなイメージのものが多いが，イン ドネシアの場合は“のんびりした”, “善人のような”, “可愛らしい”，“りこうそうな”，“好き”というよう にポジティブなイメージも含まれている。その他の評 価語で有意に多く選択されていたものは日本では“し やれた”，“きりっとした”，“明るい”，インドネシア では“女性的な”，“おとなしい”，“育ちがよい”等の 評価語であった。

日本で多く選択された“貧相な”というイメージは 特に日本人男性が多く抱いているイメージであった。 日本の男性の場合はそのほかに, “ねちねちした”, “のんびりした”，“落ち着いた”，“丸みのある”が多 いが，女性の場合は，“きりっとした”，“りこうそう な”，“はきはきとした”，“明るい”が多く，ポジティ ブな評価語が男性よりは若干多く見られる。インドネ シア女性の場合も，“うちとけた”，“美しい”という ポジティブなイメージが多くもたれているが，インド ネシア男性の場合になると, “うすっぺらな”, “女性 的な”, “古くさい”, “うわべだけの”, “甘い”, “保守 的な”というようにネガティブなものが多くなり，両 地域に共通してこの刺激に対する性差が感じられた。

数量化 III 類による分析では，インドネシアは“美 しく”（I；13.6\%+，J；5.7\%-）“女性的”（I；14.4 $\%++, \mathrm{J} ; 5.1 \%--)$ なイメージを刺激 3 にもって いるのに対して, 日本では“ふけた”（J；23.9 $\%++, \mathrm{I} ; 8.3 \%--)$ “貧相” ( J ; 22.2\%++, I ; 4.5\%-—) なイメージが中心であることがわかる. インドネシアの男性の場合は“育ちがよい”（J-m； $2.2 \%$, J-f ; $0.0 \%$, I-m ; 10.3\%++, I-f ; 3.1\%), “デリケートな” (J-m;3.3\%-, J-f；2.3\%，I-m; $11.8 \%++$, I-f；1.6\%）という方向にベクトルが向い ており，女性の方は “美しく”（J-m；5.6\%-，J-f； $5.8 \%$, I-m ; 11.8\%, I-f；15.6\%+) “可愛らしい”(J$\mathrm{m} ; 10.0 \%-$, J-f ; 3.5\%--, I-m; 13.2\%, I-f ; 25.0 $\%++）$ という評価語の方向にベクトルが向いてい る. 日本人男性の場合も“ねちねちした”（J-m;26.7 $\%++$, J-f；16.3\%，I-m；8.8\%，I-f；9.4\%), “貧相 な” (J-m；27.8\%++, J-f；16.3\%，I-m；5.9\%-, I-f；3.1\%-ー）の方向にベクトルが向いており，日 本人女性の場合は“モダンな” (J-m；15.6\%，J-f； $22.1 \%++$, I-m ; 5.9\%-, I-f ; 4.7\%-), “きりっと した” (J-m;8.9\%, J-f；22.1\%++, I-m;2.9\%-, I-f ; 4.7\%), “明るい” (J-m;10.0\%, J-f ; 2.3\%, I$\mathrm{m} ; 11.8 \%++$, I-f；1.6\%）の方向にベクトルが向い ていた. 総じて日本もインドネシアも女性はこの刺激 3 に対して“陽気”で“愉快”で“うちとけた”イメ ージをもっているのに対して, 男性は“古くさい”イ メージをもっているようである。先にも述べたように 性差が比較的多く表れているのがこの刺激の特徴とな 
っている.

刺激 4 (色黒肌) に関する分析結果 刺激 4 を第 1 選択とした評価語として総合的に最も多かったものは “女らしくない”の 237 反応であった。両地域に共通 して“女らしくない”, “派手な”, “いやらしい”, “う わべだけの”，“はきはきとした”，“意志が強そうな”, “貧相な”，“孔けた”，“うすっぺらな”，“ねちねちし た”という評価語が多く選ばれていた。

日本での特徴的な評価語は, “特色のある”, “いば った”であり，これらはインドネシアで刺激 1（色白 肌）への評価であったのが興味深い.そのほか, “軽 い”，“陽気な”，“愉快な”も日本での上位評価語であ る.インドネシアの上位評価語は, “古くさい”, “消 極的な”，“甘い”，“静かな”，“丸みのある”で，これ らは逆に日本の刺激 1 への評価と多く一致する。この 傾向はそれ以外の評価語でも同様に見られ，日本で有 意に高かったものは，“あじわいがある”，“しゃれ た”，“モダンな”, “明るい”であるのに対し，インド ネシアでは“デリケートな”, “保守的な”, “可愛らし い”，“おとなしい”，“ていねいな”等であり，総合的 に刺激 1 と刺激 4 への評価が両地域で逆転している結 果となった。

日本人男性の場合，“あじわいがある”，“うすっぺ らな”が日本人女性には観察されない上位評価語であ るのに対して, 日本人女性の場合は, “きりっとし た”，“ねちねちした”が上位評価語として特徴のある ものであった。この中で“きりっとした”は日本人女 性が刺激 3 に対しても上位に選んだ評価語であったこ とを考え合わせると，日本の女性の場合，肌の色が濃 くなると“きりっとした”印象をもち始めることがわ かる.インドネシアの男性の場合は“保守的な”とい うイメージが特徴的であり，インドネシアの女性の場 合は，“派手な”，“うちとけた”，“デリケートな”が 上位評価語として特徴的であった。

数量化 III 類の分析結果から判断すると, この刺激 に対してインドネシアでは“丸みのある”(I；34.1 $\%++$, J ; 11.9\%--) , “静かな”（I；35.6\%++, $\mathrm{J} ; 4.5 \%--)$, “保守的な” (I；28.0\%++, J ; 3.4 \%-—), “おとなしい” (I；17.4\%++, J ; 4.5 $\%--)$, “デリケート” (I；30.3\%++, J ; 3.4 \%-一) なイメージをもっており, 日本では“特色が ある” (J；69.9\%++, I；6.8\%--), “軽い”（J； $51.1 \%++$, I ; 9.8\%-ー), “いばった”（J； 58.5 $\%++$, I ; 8.3\%--), “陽気” (J；48.9\%++, I ; $6.1 \%$ - な) なイメージとのかかわりがそれぞれ多い ことがベクトルの方向からわかる.

またインドネシアの男性は“ていねい”(J-m； 5.6 \%-, J-f；5.8\%，I-m；11.8\%，I-f；15.6\%+）で “落ち着いた”イメージを抱き，日本の場合は男性も 女性も“特色のある”, “軽い” (J-m； 56.7\%++, J- f ; $45.3 \%++$, I-m ; 7.4\%--, I-f ; $12.5 \%--)$ “いばった”(J-m; 56.7\%++, J-f；60.5\%++, I$\mathrm{m} ; 7.4 \%-$, I-f ; 9.4\%-ー) イメージとのかかわ りを多くもっていることが明らかとなった。

\section{考察および結論}

白に対する嗜好性を検討するために調査 1 では一般 的な嗜好色順位における白の位置付けを確認した。 そ の結果，白は両地域で高く嗜好される色であり，日本 をはじめとする周辺アジアの地域で共通する嗜好色で あることがわかった。またその理由としては清潔感や 明るさが両地域に共通していた。

続く調査 2 では, この明るさと白さが関連深いこと から，肌の色における白さ（明るさ）に対する嗜好を 具体的な指標とし, 白への嗜好をより深く追求してみ ることにした。 その結果, 各刺激に対する評価にはそ れぞれ特徴があったが, 肌の白さに対する評価は両地 域でかなり異なっていることがわかった。

色白の肌は日本では“弱々しい”イメージが強いも のの，その弱々しさは，“おとなしくデリケートで保 守的な”印象や，“やわらかく女性的で可愛らしい” イメージとの結び付きであることがわかった。それに 対してインドネシアでは，同様に“弱々しく”“清潔 な”印象は強いものの，“いばった”イメージや“派 手な”イメージ，また“幼い”イメージなど, どちら かと言えばネガティブな傾向をもっていた。ポジティ ブな場合でも“特色のある”“しゃれた”イメージな ど，ある種の特殊性が感じられた。

しかし結果でも述べたように，このような相反する 関係は刺激 4 において逆転した形で見られる。すなわ ち日本人が刺激 4 (色黒肌) に抱いたイメージはイン ドネシア人が刺激 1 (色白肌) に抱いたイメージと一 致し比較的ネガティブな傾向をもち, 逆に日本人が刺 激 1 (色白肌) に抱いたイメージはインドネシア人が 刺激 4 (色黒肌) に抱いたイメージと多く一致しポジ ティブな傾向をもつという点である.この理由に関し ては何らかの文化的背景とその影響を感じさせるが, 本研究結果からは明らかではなく, 別な視点からのよ り深い研究が必要と考えられる。

またインドネシアの場合, 肌の色の濃さは加龄を意 味するようであることが，“幼い”“ふけた”という評

3 特に西洋絵画では年配者には褐色の肌, 若者にはたとえ男 性であっても色白の肌のように，老若の対比を肌の色で表現し た。またエジプトやローマの壁画でも男女の肌の色分けを慣習 的に行っており，男は褐色，女は白，と明確な性別の区分を示 す記号としていたようである. 1400 年ごろに書かれたと思われ るイタリア初期ルネッサンスの画家であるCennini の書 (“Il libro dell'arte”) にも既にその約束事は記されている.このよう に色白肌は女性らしさと結びつき, 褐色の肌は女性らしくない, すなわち男性的なイメージと結びつく背景は絵画にも見出せる. 
価語とのかかわりでわかった。すなわち “幼い”と刺 激 1 (色白肌), “尒けた”と刺激 4 (色黒肌) との結 び付きがインドネシアでは比較的多く見られた。また 日本では，刺激 1 (色白肌), インドネシアでは刺激 2 （普通肌の色白寄り）に対してそれぞれ“女性らしい 感じ”を抱き，逆に刺激 4 (色黒肌) に対しては両地 域とも“女らしくない感じ”をもっていた。このよう に年齢の老若や性別（男らしさ・女らしさ）を肌の色 の濃さで対比させるような概念は既に紀元前の壁画に も見られるように一種の記号化された概念や技法でも あり，これらの結果はそのような一般概念の影響とも 考えられる3.

有意な性差も多く観察された。特に刺激 3 (普通肌 の色黒寄り）では日本もインドネシアもネガティブな 評価をしているのが男性であり ( J-m : 貧相な, 㸚ち ねちした等. I-m：うすっぺらな，古くさい，うわべ だけの等)，女性はむしろポジティブな受け止め方を していた（J-f：きりっとした，りこうそうな，はき はきとした，明るい等. I-f：うちとけた，美しい等).

美しさの判断に関して言及するならば，色白肌を “美しい”と評価しているのは日本人の方であり（刺 激 $1 ； \mathrm{~J} ; 60.8 \%$ I I 39.4\%), インドネシアの場合は むしろ普通肌の色白寄りを“美しい”と選択していた (刺激 $2 ： \mathrm{~J} ; 31.3 \% ， \mathrm{I} ; 53.0 \%$ )。また嗜好性という 点から“好き”という評価語に着目するならば，“好 き”と思われていたのは, 日本もインドネシアも, 最 も色白の印象をもつ刺激 1 よりも刺激 2 の普通肌の色 白寄りであったことが明らかとなった。更に“扔だや かで魅力的で知性的”というパーソナリティーと多く 関連しているのは, 両地域とも刺激 2 の普通肌の色白 寄りであり, “陽気で親しみやすくあたたかいパーソ ナリティー”としてとらえられているのは, 刺激 3 の 普通肌の色黒寄りであることを考えあわせると, パー ソナリティーの側面からは肌の色は中庸であることが 最も好ましいようである。

色彩に対する赀好は具体的な形態を伴った場合に変 化することは林・相馬 (1990) の研究でも明らかであ るが，本研究からも同様の結果となった．すなわちア ジアに扔いて高く嗜好される白は, その嗜好の背景の 一つに明るさとの関連もあるが，肌の色という具体的 事象になった場合, 肌の白さの暏好に対する影響要因
には性差や文化差など個体要因や環境要因等の多くの 側面がより複雑にかかわりその嗜好構造は変化してく る。

但し肌の色における白さが重んじられるのは，その 貴族的なイメージとデリケートで弱々しいもろさを含 む，ある種の “特殊性”が関連しているようであるこ とも本研究の結果から明らかとなった。このことはま た日本をはじめとする周辺アジア地域に共通する白赀 好がその “特殊性”や“稀少性” から次第に珍重さ れ，徐々に好まれていったという変容を示唆するのか もしれない.

\section{引用文献}

林 知己夫・相馬一郎 1990 パッケージデザインの 基礎研究 花王株式会社調査部

岩下豊彦 1983 SD法によるイメージの測定 川島 書店

小林嗣幸 1967 おしゃれの色彩 日本色研事業株式 会社

日本色彩研究所色彩情報研究会 1992 第 12 回消費 者の色彩嗜好調査報告書デー夕集 (財) 日本色彩研 究所

齋藤美穂 1981 色彩嗜好に打けるCross-Cultural Research 早稲田大学文学研究科紀要, 27, 211-216. 齋藤美穂 1992 アジアに扔ける色彩嗜好の国際比較 研究 (1) 一日韓比較・白嗜好に着目して—— 日 本色彩学会誌, 16, 1-10.

Saito, M. 1994 A cross-cultural study on color preference in three Asian cities: Comparison between Tokyo, Taipei and Tianjin. Japanese Psychological Research, 36, 219-232.

齋藤美穂・冨田正利・向後千春 1991 日本の四都市 における色彩嗜好 (1) 一一因子分析的研究一一 日 本色彩学会誌, 15, 1-12.

齋藤美穂・冨田正利・山下和幸 1991 日本の四都市 に打ける色彩嗜好 (2)一一クスター分析によるラ イフスタイル特性の類型化——日本色彩学会誌, 15, 99-108.

Tsukada, I., Funatsu, K., \& Sato, M. 1964 A study on color preference. Acta Chromatica, 1, 131-146.

-1995.9.4 受稿, 1996. 1.20 受理— 